\title{
地域循環共生圈とライフサイクル思考
}

\section{Life Cycle Thinking and Regional Circular and Ecological Sphere}

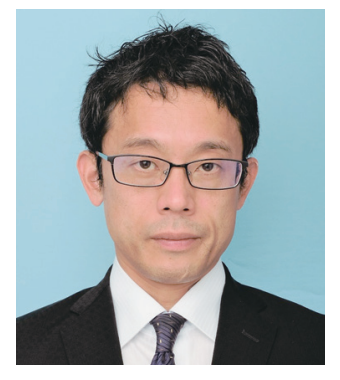

特集幹事 大西 悟 $1, *$

Editor-in-Chief, Journal of Life Cycle Assessment, Japan Satsohi OHNISHI ${ }^{1, *}$

2018 年 4 月に閣議決定した第五次環境基本計画の中で、 地域循環共生圈の理念が提示されました。昨今の脱炭素、 SDGsの潮流もあり、環境政策にとどまらず、重要な目標像 の1つとして、国内各地において取り組みが活発化してきて います。この理念の実現に当たっては、地域における資源・ エネルギーの循環と共生関係をライフサイクル思考でデザイ ンし、総合的に評価していくことが1つの貢献策になります。 そこで、本特集号では、地域循環共生圈の実現という課題 に対し、ライフサイクル思考とLCA研究の貢献策を考える きっかけとして、最新の知見を提供することを目指しています。 なお、前号「地域レベルで考える持続可能性」では、地域 の物質収支を踏まえた環境・経済・社会評価をテーマに取 り上げています。地域循環共生圈の形成に向けて非常に重 要な視点であり、LCA研究が特に期待される分野です。前 号の特集をあわせてご覧くださると理解が深まると思います。 本特集号は、中長期的な学術貢献に向けた萌芽的な論考お よび実務・実際的な取り組みに着目しています。

本特集号は、解説 4 本を掲載しています。

大西による地域循環共生圈に対するLCA研究の貢献を論 じる解説では、これまでのLCA学会誌の特集号の記事を手 掛かりに、新しい研究の動向も踏まえて、地域循環共生圈 とLCA研究との関係を記述しています。地域循環共生圈が 日本の環境政策を網羅する概念であることもあり、広範にわ たってこれまでのLCA 研究との関連することを明らかにして います。一方、地域循環共生圈は、中長期にわたって継続 的に実施していく必要があること、ステークホルダーが多岐 にわたり、関係性も複雑であること、その中で学術分野が 果たす役割も変わりつつあることを踏まえ、オープン・イノ ベーションを通じたインベントリ構築、ライフサイクル・デザ イン思考、地域の資本形成の重要性を示唆しています。

五味の解説では、地域循環共生圈という広範で複雑な概 念を「地域」、循環」、「共生」の理念ごとに解説しています。 そして、実務的に理解の難しい「圈域」の概念について、国 の政策・計画論の観点から整理するとともに、「自然的一人 為的」と「記述的一規範的」といった軸に沿って整理した研 究成果を報告しています。また、地域循環共生圈はローカル
SDGsと称されるように、多くの指標、要件を統合的に用い ることが求められます。本解説では、それらを分解し、構 造化する枠組みを提示し、それを応用した事例を紹介して います。地域循環共生圈づくりは、実践事例の蓄積が重要 であるとともに、理念の理解に基づく学術展開が重要です。 本解説が、地域固有の取り組みを推進する共通の知識基盤 となることを期待します。

永冨・河野・東は、地域循環共生圈づくりの実践事例とし て、北海道古平町、福島県大熊町、富山県富山市のコンサ ルティング業務の経験をもとに、その業務の枠組みを解説し、 今後の方向性を論じています。地域循環共生圈は、エネル ギー、防災、交通・移動、ライフスタイル、ビジネスが事業 化に向けた要素とされますが、昨今の脱炭素の潮流から主 に地域エネルギーに関連する解説に絞っています。ただし、 地域エネルギーは、多くの他の要素と関連しています。実務 での経験から、将来的な方向性として、地域のステークホル ダー自身の地域課題の理解と地域循環共生圈づくりを推進 する地域プラットフォームの構築を課題としており、1つの事 業にとどまらない形成推進策の検討が必須と読み取れます。

高瀬は、ネットゼロとスコープ 3 に関する最新情勢をもとに、 $\mathrm{CO}_{2}$ 吸収を含めたライフサイクル思考の高まりについて記事 にしています。ここでは、地域循環共生圈を明記していませ んが、今後の形成推進において脱炭素とのつながりが重要 であることからテーマとして取り上げています。特に、自治 体・企業といった非政府主体のネットゼロとスコープ 3 は、 LCA研究ともかかわる重要なテーマであるとともに、開発 途上であることから最新情勢をお届けします。スコープ3の 削減は、一地域、一企業では検討できないことから、複数 セクター、地域での算定と削減策、土地利用と $\mathrm{CO}_{2}$ 除去の 算定の検討手法が重要であり、地域循環共生圈では必須の 項目といえます。

地域循環共生圈・ローカル SDGsの実現に向けた取り組み は、脱炭素の潮流を受けて、実現に向けたターニングポイン 卜を迎えつつあります。ライフサイクル思考は、その推進に 大きな貢献ができると思います。本特集号が、この理念の 実現にむけた取り組みに役立つことを期待しています。 